Contemporary Encounters with Ancient Metaphysics 
We would like to dedicate this volume to our partners: qui nolet fieri desidiosus, amet. 


\section{Contemporary Encounters with Ancient Metaphysics}

Edited by Abraham Jacob Greenstine and Ryan J. Johnson 
Edinburgh University Press is one of the leading university presses in the UK. We publish academic books and journals in our selected subject areas across the humanities and social sciences, combining cutting-edge scholarship with high editorial and production values to produce academic works of lasting importance. For more information visit our website: edinburghuniversitypress.com

(C) editorial matter and organisation Abraham Jacob Greenstine and Ryan J. Johnson, 20I7 (C) the chapters their several authors, 2017

Edinburgh University Press Ltd

The Tun - Holyrood Road, I 2(2f) Jackson's Entry, Edinburgh EH8 8PJ

Typeset in Io/I2 Adobe Sabon by IDSUK (DataConnection) Ltd, and printed and bound in Great Britain by CPI Group (UK) Ltd, Croydon CRo 4 YY

A CIP record for this book is available from the British Library

ISBN 978 I 4744 I 2094 (hardback)

ISBN 978 I 4744 I 2 IO O (webready PDF)

ISBN 978 I 4744 I2I I 7 (epub)

The right of Abraham Jacob Greenstine and Ryan J. Johnson to be identified as the editors of this work has been asserted in accordance with the Copyright, Designs and Patents Act I988, and the Copyright and Related Rights Regulations 2003 (SI No. 2498). 